\title{
Analysis Of Smoking Behavioral Factors In Adolescents During Covid-19 Pandemic In Aru Islands Maluku
}

\author{
Novalin Wakim, Milla Evelianti Saputri*, Milya Helen \\ Universitas Nasional, Jakarta, Indonesia \\ Correspondingauthor:milla.evelianti@civitas.unas.ac.id
}

\begin{abstract}
Background: Smoking has become a habit of Indonesian society. This behavior is not only found in adults but also in adolescents over 15 years. Indonesia ranks third out of the ten largest smoking countries in the world. There are $33.37 \%$ of the population of the Aru Islands aged over 15 years who have a smoking habit. This behaviour in adolescents occurs due to invitations from peers, being ridiculed by friends if they do not smoke, desire to try new things, fad, addicted, imitating parents and the influence of the mass media.

Purpose: This study aimed to determine the factors of smoking behaviour in adolescents in Aru Islands, Maluku.

Methods: This study used a cross sectional approach with a total sample of 72 respondents using purposive sampling technic. This research used questionnaire as instrument, whereas the data were analysed using the chi-square test to relate the analysed data to the chi-square of age, education, knowledge, and stress levels.

Results: The results shows that there are relationships between age (p. value 0.015), education ( $p$. value 0.005$)$, knowledge ( $p$. value 0.038 ) and stress levels ( $p$. value 0.035 ) on smoking behaviour in the Aru Islands region, Maluku.

Conclusion: The hope is that with good education and knowledge, teenagers in these areas will be more easily exposed to information about the dangers and impacts of smoking at a young age and not use cigarettes as an escape to deal with stress.
\end{abstract}

Keywords: Adolescents, Covid-19, Smoking Behavioral Factor. 


\section{Journal Of Nursing Practice}

http://thejnp.org

ISSN: 2614-3488 (print); 2614-3496 (online)

Vol.5 No.1. October 2021. Page.196-203

\section{BACKGROUND}

Smoking is a behavior that we often encounter in various places and it has become a habit in Indonesian society. Even smokers in Indonesia are not only among adults, but also in adolescents over 15 years (Syahry A, 2020). Smoking is also a public health problem because it cause a risk factor for several diseases including: cardiovascular disease; cerebrovascular disease; impotence; and even various types of cancer caused by various chemicals or particles in cigarette smoke (Salamau MS, et al. 2021).

Smoking behavior is an activity of burning and smoking a cigarette (Rumuat A, et al, 2021). Smoking behavior can be found in homes, offices, public transportation, streets, hangouts, parks, and even educational environments (Susanty D S \& Saputra HA, 2020). A smoker who continuously smokes for a long period of time will face the possibility of death three times higher than those who are not smokers (Nasution in Baharuddin, 2017).

During adolescence, individuals experience psychological development and identification patterns from childhood to adulthood (WHO, 2017). Teenagers who like to experiment always want to try a behavior such as smoking. Smokers who start smoking at an early age and continue to smoke for life will eventually die of smoking-related diseases (Nurhaman M \& Anasari T, 2021). WHO defines adolescents as individuals who are in the age period ranging from 10-19 years, while the United Nations says that young people are for 15-24 years individual. According to The Health Research and Service Administration Guidelines of the United States, the age range of adolescents is 11-21 years and is divided into 3 stages, which are: early adolescence (11-14 years); middle adolescence (15-17 years); and late adolescence (18-21 years).

According to the Indonesian Statistics, the percentage of smoking population aged over 15 years in Indonesia in 2018: 32.20\%; 2019: 29.03\%; 2020: 28.69\%. Meanwhile, based on the 2018 Basic Health Research (Riskesdas) data, the prevalence of smokers over 15 years is reached $33.8 \%$.

According to RISKESDAS 2018, there are some categories of smoker in Maluku. Daily smokers reach $22.05 \%$; occasionally smokers $6.17 \%$. Smoker category by age groups: 10-14 years reach $2.81 \%$; $15-14$ years, 8.87\%; 20-24 years, 9.97\%. Smoker category for special age group: $10-18$ years, $7.67 \%$; $15+$ years, $12.16 \%$; $10+$ years, $12.14 \%$. Smoker category based on sex: male $12.19 \%$ and female $8.66 \%$. Smoker category based on education: did not go to school at all, 12.35\%; not finished elementary school, 10.67\%; graduated elementary school, $11.37 \%$; junior high school graduate, $12.01 \%$; high school graduate, $12.37 \%$; graduated of higher education, $14.19 \%$. According to the 2020 Aru Islands Statistics Data, the population aged 15 years and over who smoke is $33.37 \%$ in the Aru Islands Regency. The high level of smokers in Indonesia is currently very at risk of contracting Covid-19 which attacks the respiratory system in humans.

\section{METHODS}

This research was designed as quantitative research with cross sectional approach. The population in this study were all male adolescents aged 15-24 years in RT 96 Galaidubu Village. The sampling technique in this study used purposive sampling. Data were analyzed using chi-square statistical test to test the relationship or effect of two variables.

\section{RESULT}

The results of the study of factors related to smoking behavior in adolescents are presented in the following table: 


\section{Journal Of Nursing Practice}

Table 1. Frequency Distribution of Respondents Age of RT.96 Galaidubu Village people, Aru Islands in 2021

\begin{tabular}{lll}
\hline Age & F & Percent $(\%)$ \\
\hline$<18$ years old & 19 & 26.4 \\
\hline$>18$ years old & 53 & 73.6 \\
\hline Total & 72 & 100
\end{tabular}

Based on table 4.1, the results obtained are respondents who do not smoke at the age of $<18$ years are 19 respondents $(26.4 \%)$, respondents who behave smoking age $>18$ years are 53 respondents $(73.6 \%)$.

Table 2. Distribution of Education Frequency of Respondents in RT 96 Galaidubu Village, Aru Islands in 2021

\begin{tabular}{lll}
\hline Education & F & Percent (\%) \\
\hline Elementary & 11 & 15.3 \\
\hline Junior High School & 31 & 43.1 \\
\hline Senior High School & 20 & 27.8 \\
\hline Higher Education & 10 & 13.9 \\
\hline Total & 72 & 100 \\
\hline
\end{tabular}

Table 4.2 shows that respondents with elementary education were 11 respondents (15.3\%); respondents with junior high school education were 31 respondents $(43 \%)$; respondents with high school education were 20 respondents $(27.8 \%)$; respondents with higher education were 10 respondents $(13.9 \%)$.

Table 3. Distribution of Knowledge Frequency of Respondents in RT.96 Galaidubu Village, Aru Islands in 2021

\begin{tabular}{lll}
\hline Knowledge & F & Percent $(\%)$ \\
\hline Good & 61 & 84.7 \\
\hline Moderate & 11 & 15.3 \\
\hline Total & 72 & 100 \\
\hline
\end{tabular}

Table 4.3 shows that respondents with good knowledge are 61 respondents $(84.7 \%)$; respondents with sufficient knowledge are 11 respondents $(15.3 \%)$.

Table 4. Frequency Distribution of Respondents Stress Level in RT.96 Galaidubu Village, Aru Islands in 2021

\begin{tabular}{lcl}
\hline Stress level & F & Percent $(\%)$ \\
\hline Normal $(0-14)$ & 30 & 41.7 \\
\hline Mild (15-18) & 17 & 23.6 \\
\hline Moderate (19-25) & 15 & 20.8 \\
\hline Heavy $(26-33)$ & 3 & 4.2 \\
\hline Severe $(>34)$ & 7 & 9.7 \\
\hline Total & 72 & 100
\end{tabular}

Table 4.4 shows that respondents with normal stress level are 30 respondents $(41.7 \%)$; respondents with mild stress level are 17 respondents $(23.6 \%)$; respondents with moderate stress level are 15 respondents $(20.8 \%)$; respondents with heavy stress level are 3 respondents (4.2\%); respondents with severe stress level are 7 respondents $(9.7 \%)$. 


\section{Journal Of Nursing Practice}

Table 5. Frequency Distribution of Smoking Behavior of Respondents in RT.96 Galaidubu Village, Aru Islands in 2021

\begin{tabular}{lll}
\hline Smoking Behavior & F & Percent (\%) \\
\hline Not smoking & 16 & 22.2 \\
\hline Smoking & 56 & 77.8 \\
\hline Total & 72 & 100 \\
\hline
\end{tabular}

Table 4.5 shows that respondents with smoking behavior are outnumbered respondents without smoking behavior, which are 56 respondents $(77.8 \%)$ compared to 16 respondents $(22.2 \%)$.

Table 6. Relationship between Age and Smoking Behavior in Adolescents in RT.96 Galaidubu Village, Aru Islands in 2021

\section{Smoking Behavior}

\begin{tabular}{|c|c|c|c|c|c|c|c|}
\hline & $\begin{array}{l}\text { Not } \\
\text { Smoking }\end{array}$ & Smok & & Total & & \multirow{2}{*}{\multicolumn{2}{|c|}{ P. Value }} \\
\hline \multicolumn{6}{|l|}{ Age } & & \\
\hline & $\mathrm{n} \%$ & $\mathrm{~N}$ & $\%$ & $\mathrm{n}$ & $\%$ & & \\
\hline$\leq 8$ & 842.1 & 11 & 57,9 & 19 & 100 & & \\
\hline Years old & & & & & & 0,015 & 13,328 \\
\hline $\begin{array}{l}>18 \\
\text { Years old }\end{array}$ & $\begin{array}{ll}8 & 15.1\end{array}$ & 45 & 84.9 & 53 & 100 & & \\
\hline Total & 22.2 & 56 & 77.8 & 72 & 100 & & \\
\hline
\end{tabular}

Table 4.6 shows that respondents aged $>18$ years who do not smoke are 8 respondents (15.1\%); respondents who smoke aged $\leq 18$ years are 11 respondents $(57.9 \%)$. The results of the chi-square test have a p-value of 0.015 ( $\mathrm{p}<0.05$, meaning $\mathrm{H} 0$ is rejected), which means that there is a relationship between age and smoking behavior in adolescents.

Table 7. Relationship of Education to Smoking Behavior in Adolescents in RT.96 Galaidubu Village, Aru Islands in 2021

\begin{tabular}{|c|c|c|c|c|c|c|c|}
\hline \multicolumn{6}{|c|}{ Smoking Behavior } & & \multirow[b]{2}{*}{ P. Value } \\
\hline \multirow{2}{*}{ Education } & \multicolumn{2}{|c|}{ Not Smoking } & \multicolumn{2}{|c|}{ Smoking } & \multicolumn{2}{|l|}{ Total } & \\
\hline & $\mathrm{n}$ & $\%$ & $\mathrm{~N}$ & $\%$ & $\mathrm{n}$ & $\%$ & \\
\hline Elementary & 7 & 58.3 & 5 & 41.7 & 12 & 100 & 0,005 \\
\hline Junior high School & 8 & 25.8 & 23 & 74.2 & 31 & 100 & \\
\hline $\begin{array}{l}\text { Senior High } \\
\text { School }\end{array}$ & 2 & 9.5 & 19 & 90.5 & 21 & 100 & \\
\hline Higher Education & 0 & 0.0 & 8 & 100 & 22 & 100 & \\
\hline Total & 17 & 22.2 & 55 & 77,8 & 72 & 100 & \\
\hline
\end{tabular}

Table 4.7 shows that respondents with primary school education who smoked were 5 respondents (41.7\%); junior high school education who smoked 23 respondents $(74.2 \%)$; high school education respondents who did not smoke 2 respondents $(9.5 \%)$; higher education graduated without smoking behavior 0 respondents $(0.0 \%)$. The results of the chisquare test have a p-value of 0.005 ( $p<0.05$, meaning $\mathrm{H} 0$ is rejected), which means that there is a relationship between education and smoking behavior in adolescents. 


\section{Journal Of Nursing Practice}

http://thejnp.org

ISSN: 2614-3488 (print); 2614-3496 (online)

Vol.5 No.1. October 2021. Page.196-203

Table 8. Relationship of Knowledge to Smoking Behavior in Adolescents in RT.96 Galaidubu Village, Aru Islands in 2021

Smoking Behavior

Not Smoking Smoking Total P. Value OR

Pengetahuan

\begin{tabular}{lclllllll}
\cline { 2 - 6 } & $\mathrm{n}$ & $\%$ & $\mathrm{n}$ & $\%$ & $\mathrm{n}$ & $\%$ & & \\
\cline { 1 - 6 } Good & 15 & 28.3 & 38 & 71.7 & 53 & 100 & 0,038 & \multirow{2}{*}{7.105} \\
Moderate & 1 & 5,3 & 18 & 94,7 & 11 & 100 & & \\
\hline Total & 16 & 22,2 & 56 & 77,8 & 72 & 100 & &
\end{tabular}

Table 4.8 shows that respondents who have good knowledge and do not smoke are 15 respondents $(28.3 \%)$, while respondents who have moderate knowledge and smoking behavior are 18 respondents $(94.7 \%)$. The results of the chi-square test have a $p$-value of $0.038(p<0.05$ $=$ Ho is rejected) which means that there is a relationship between knowledge and smoking behavior in adolescents.

Table 9. Relationship between Stress Levels and Smoking Behavior in Adolescents in RT.96 Galaidubu Village, Aru Islands in 2021

\begin{tabular}{|c|c|c|c|c|c|c|c|}
\hline \multicolumn{7}{|c|}{ Smoking Behavior } & \multirow{3}{*}{ P. Value } \\
\hline \multirow[t]{2}{*}{ Stress level } & \multicolumn{2}{|c|}{ Not Smoking } & \multicolumn{2}{|c|}{ Smoking } & \multicolumn{2}{|c|}{ Total } & \\
\hline & $\mathrm{n}$ & $\%$ & $\mathrm{n}$ & $\%$ & $\mathrm{~N}$ & $\%$ & \\
\hline 0-14 Normal & 13 & 37.1 & 22 & 62.9 & 35 & 100 & 0,035 \\
\hline 15-18 Mild & 0 & 0.0 & 15 & 100 & 15 & 100 & \\
\hline 19-25 Moderate & 2 & 13.3 & 13 & 86.7 & 15 & 100 & \\
\hline 26-33 Heavy & 0 & 0,0 & 3 & 100 & 3 & 100 & \\
\hline$>34$ Severe & 1 & 25.0 & 3 & 75.0 & 4 & 100 & \\
\hline Total & 16 & 22.2 & 56 & 77.8 & 72 & 100 & \\
\hline
\end{tabular}

Table 4.9 shows that respondents who have normal stress level who do not smoke are 13 respondents $(37.1 \%)$; respondents with mild stress level who do not smoking are 0 respondents; respondents with moderate stress level who smoking are 13 respondents $(86.7 \%)$, respondents with heavy stress level are 3 respondents who smoking are 3 respondents $(100 \%)$, and those with severe stress level who smoking are 3 respondents $(75.0 \%)$. The results of the chi-square test have a $p$-value of $0.035(p<0.05=$ Ho is rejected $)$ which means that there is a relationship between stress levels and smoking behavior in adolescents.

\section{DISCUSSION}

The Chi-Square test was carried out at RT.96 Galaidubu Village in July 2021. The results showed that there was a relationship between age and smoking behavior, a $p$ value of $0.015<0.05$ means that there is a relationship between age and smoking behavior in adolescents; for the relationship between education and smoking behavior, $p$ value 0.000 which means that there is a relationship between education and smoking behavior; for the relationship between knowledge and smoking behavior $p$ value 0.038 ; and for the relationship of stress with smoking behavior, $p$ value 0.035 , which means that there is a significant relationship between stress and smoking behavior. 


\section{Journal Of Nursing Practice}

http://thejnp.org

ISSN: 2614-3488 (print); 2614-3496 (online)

Vol.5 No.1. October 2021. Page.196-203

This is in line with the research by Elvi Juliansyah \& Achmad Rizal (2018) on factors of age, education and knowledge with smoking behavior in the working area of Sungai Duren Health Center, Sintang Regency, which said that there was a difference in the proportion of smoking behavior between those aged less than 18 years and over 18 years (there was a significant relationship with smoking behavior) with statistical test results obtained $p$ value $=0.000(p<0.05)$. For education, this research is in line with the research by Rusdani \& Nopri Esmiralda (2019) regarding the relationship between education level and smoking behavior in male employees at the University of Batam, which said that there was a significant relationship between education level and smoking behavior with the result of statistical test $p$ value $=0.018(\mathrm{p}<0.05)$.

For the knowledge factor, this research is in line with the research by Novia Oktaviani, et al (2019) regarding Factors Associated with Smoking Behavior in Male Students at Pakuan University, Bogor, West Java Province in 2018, that there is a relationship between knowledge and smoking behavior with the results of the statistical test $\mathrm{p}$ value $=0.008$ $(p<0.05)$; and for stress this research is in line with Kurnuawati's research (2017) on the Relationship Between Stress and Smoking Behavior in Adolescent Boys Class X and XI at SMK 1 Jiwan, Madiun Regency, that there is a significant relationship between stress with smoking behavior with statistical test results $p$ value $0.000(p<0.05)$.

Age under 18 years is a time for a child to face a period of change and development. In the age less than 18 years, an individual is looking for his identity to enter adolescence, so he is more easily influenced by various media, such as: peers; cigarette advertisements; and the role of parents (Juliansyah and Rizal 2018). Lawrence Green Theory in Notoatmojo (2012) states that behavior is motivated or influenced by several factors, which one of the predictive factors is education.

Researchers assume that human behavior is strongly influenced by various factors as stated above, and in this study it was seen that age, education, knowledge and stress levels were related to smoking behavior in adolescents in the Galaidubu village so there was a need for monitoring related to age, education, and level of knowledge, and controlling stress levels that will lead to adolescent smoking behavior.

\section{CONCLUSION}

Age $>18$ years, higher education, good knowledge and mild stress levels will be associated with adolescent behavior not to smoke.

\section{REFERENCES}

Amelia Rumuat., Adisti A. Rumayar., Asep Rahman. (2021). HubunganPengetahuan dan Sikap Dengan Tindakan Merokok Di Sesa Mariri Satu Kecamatan Poigar, KESMAS, $10(4), 43$.

Alvi Syahry, (2020), Perilaku Merokok Pada Remaja, Edukasi IPS, 4(2), DOI: https://doi.org/10.21009/EIPS.004.2.05.

Badan Pusat Statistik., (2021), Presentase Merokok Pada Penduduk Umur $\geq 15$

Tahun Menurut Provinsi (Persen), 2018-2020, Jakarta.

Bawuna N H., et al (2017), Hubungan Antara Tingkat Stres Dengan Perilaku Merokok Pada Mahasiswa Fakultas Teknik Universitas SAM Ratulangi, Jurnal Content, 5(2).

Citra Widya Mustika Sinaga (2018), Hubungan Pengetahuan dan Sikap Remaja Perokok Terhadap Perilaku Merokok diKelurahan Baru Kecamatan SiantarUtara Tahun 2017, Skripsi, Fakultas Kesehatan Masyarakat Universitas Sumatra Utara Medan.

Elvi Juliansyah., Achmad Rizal. (2018). Faktor Umur, Pendidikan, dan Pengetahuan Dengan Perilaku Merokok di Wilayah Kerja Puskesmas Sungai Duren, Kabupaten Sinteng, 


\section{Journal Of Nursing Practice}

http://thejnp.org

ISSN: 2614-3488 (print); 2614-3496 (online)

Vol.5 No.1. October 2021. Page.196-203

Kesehatan Masyarakat, 17(1), 97-98, 102-104. P-ISSN: 1412-3746.

Ellyvon, P., (2020), Jumlah Perokok di Indonesia Tinggi, Ahli Desak Pemerintah Lakukan5Hal.KOMPAS.com,https://www.kompas.com/sains/read/2020/0

9/25/200500823/jumlah-perokok-di-indonesia-tinggi-ahli-desak- pemerintahlakukan-5-hal.

Elon Y \& Malinti E. (2019), Fenomena Merokok Pada Anak Usia Remaja: StudiKualitatif, Klabat Journal Of Nursing (KNJ), 1(1).

Gani Apriningtyas Budiyati., Dian Nur Adkhana Sari., Suryanti. (2021).Pengetahuan, Sikap, Dan Perilaku Meroko Pada Remaja, Jurnal Ilmiah Permas: Jurnal Ilmiah STIKES Kendal, 11(1).

Hilyana Hilyana., Suryanti Hasbullah., H. Muzakkir. (2013). Hubungan Tingkat Stres Terhadap Perilaku Merokok Remaja Siswa Di SLTP 30 Makassar Kota Makassar, Jurnal Ilmiah Kesehatan Diagnosa, 2(4). ISSN: 2302-1721.

Heryanti V, et al (2020), Determinan Perilaku Merokok Pada Remaja Pria: LiteraturRiview, Jurnal Keperawatan Komunitas, 5(1). https://m.diadona.id.family/pengertianremaja-menurut-para-ahli-dan-who- 200530i.html

Istiana D, et al (2021), Analisis Determinan Perilaku Merokok Pada Remaja DaerahPesisir Kota Mataram, Jurnal Keperawatan Jiwa (JKJ): Persatuan Perawat Nasional Indonesia, 9(2), e-ISSN: 2655-8106, p-ISSN: 2338-2090.

Kurniawati, D., (2017), Hubungan Antara Stres Dengan Perilaku Merokok Pada Remaja Laki-laki Kelas X dan XI di SMK 1 Jiwan Kabupaten Madiun, Skripsi, Program Studi Keperawatan STIKES Bhakti Husada Mulia, Madiun.

KEMENKES., Info Covid-19 Kabupaten Kepulauan Aru Periode 19 Juli 2021, Dinas Kesehatan Kabupaten Kepulauan Aru.

Laporan Provinsi Maluku, RISKESDAS 2018/Badan Penelitian dan Pengembangan Kesehatan. ISBN 978-602-373-139-8.

Mukti Nurahmah., Tri Anasari. (2021). Hubungan Pengetahuan Tentang Rokok Dan Teman Yang Merokok Dengan Perilaku Merokok Pada Remaja, JurnalBina Cipta Husad, $17(1)$.

Munir M, (2019), Gambaran Perilaku Merokok Pada Remaja Laki-laki, Jurnal Kesehatan, 12(2).

Marcus A D, et al (2021), Hubungan Antara Tingkat Stres Dengan PerilakuMerokok Pada Mahasiswa Fakultas Teknik Sipil Universitas Nusa Cendana, Cendana Medical Journal, 21(1)

Oktaviani N., et al (2019), Faktor-faktor Yang Berhubungan Dengan Perilaku Merokok Pada Mahasiswa Pria Di Universitas Pakuan Bogor Provinsi Jawa Barat Tahun 2018, Jurnal Mahasiswa Kesehatan Masyarakat, 2(1).

Putu Rias Andreani., Ni Kadek Muliawati., Ni Luh Gede Puspita Yanti. (2020). Hubungan Tingkat Stres dengan Perilaku Meroko pada Remaja Laki-Laki di SMA Saraswati 1 Denpasar, Jurnal Akademika Baiturrahim Jambi, 9(2),226.

Putri Dwi Ardiyanti., et al (2020), Gambaran Pengetahuan Perilaku Merokok di Masa Pandemi Covi-19 pada Kalangan Remaja Laki-laki di Wilayah Jabodetabek Tahun 2020, Jurnal Ilmu Kesehatan Indonesia (JIKSI), 1(2), E-ISSN: 2745-8555.

Puspawinarta Helga \& Prasetyo Aries, (2021), Kajian Faktor-faktor Perilaku Merokok pada Remaja di Desa Krajan Kecamatan Parang Kabupaten Magetan, Jurnal Profesi Kesehatan Masyarakat, 2(1). ISSN: 2774-8502.

Riazul Jannah, (2021), Tingkat Stres Mahasiswa Mengikuti Pembelajaran Daring Pada Masa Pandemi Covid-19, Riset dan Pengabdian Masyarakat, 1(1), 133.

Rizki, Viata., (2020). Analisis Faktor Prilaku Merokok Pada Polisi Di Asrama 


\section{Journal Of Nursing Practice}

Polisi Lamjamee Kecamatan Jaya Baru Kota Banda Aceh, Skripsi, Fakultas Kesehatan Masyarakat Universitas Muhammadiyah Aceh, Banda Aceh. 13,16-18,22-29,32.

Rusdani \& Nopri Esmiralda, (2019), Hubungan Tingkat Pendidkan Dengan Perilaku Merokok Pada Karyawan Laki-laki Universitas Batam, Zona Kedokteran, 9(3).

Sawitri H., et al (2020), Karakteristik Perilaku Merokok Mahasiswa Universitas Malikussaleh 2019, Jurnal Averrous, 6 (1).

Statistik Kesejahteraan Rakyat Kabupaten Kepulauan Aru 2020., Badan Pusat Statistik Kabupaten Kepulauan Aru., ISBN: Nomor Publikasi 8105050.2015, Katalog: 4101002.8105

Sri Maharani Salamu., et al, (2021), Hubungan Antara Pengetahuan dan Sikap Dengan Perilaku Merokok Peserta Didik SMA Negeri 1 LOLAK Kabupaten Bolaang Mongondow, Jurnal KESMAS, 10(3).

Shantry, D.S dan Harry, A.S, (2020), Promosi Kesehatan Tentang Bahaya MerokokPada Usia Remaja Di SMK N 1 Bukittinggi, Empowering Soclety Journal, 1(1).

Wirenviona, R, dan Riris., A.A.I.D.C., (2020), Edukasi Kesehatan Reproduksi Remaja, Airlangga University Press, Surabaya, 1-3. 